\title{
GCU
}

Glasgow Caledonian

University

University for the Common Good

\section{The contemporary relevance of Karl Polanyi to critical social enterprise scholarship}

\author{
Roy, Michael J.; Grant, Suzanne
}

Published in:

Journal of Social Entrepreneurship

DOI:

10.1080/19420676.2019.1621363

Publication date:

2020

Document Version

Author accepted manuscript

Link to publication in ResearchOnline

Citation for published version (Harvard):

Roy, MJ \& Grant, S 2020, 'The contemporary relevance of Karl Polanyi to critical social enterprise scholarship', Journal of Social Entrepreneurship, vol. 11, no. 2, pp. 177-193. https://doi.org/10.1080/19420676.2019.1621363

\section{General rights}

Copyright and moral rights for the publications made accessible in the public portal are retained by the authors and/or other copyright owners and it is a condition of accessing publications that users recognise and abide by the legal requirements associated with these rights.

Take down policy

If you believe that this document breaches copyright please view our takedown policy at https://edshare.gcu.ac.uk/id/eprint/5179 for details of how to contact us. 


\title{
The contemporary relevance of Karl Polanyi to critical social
}

\section{enterprise scholarship}

\author{
Michael J. Roy ${ }^{1}$ and Suzanne Grant ${ }^{2}$ \\ ${ }^{1}$ Y unus Centre for Social Business and Health, Glasgow Caledonian University, UK \\ ${ }^{2}$ New Zealand Social Innovation and Entrepreneurship Research Centre, Massey University, \\ New Zealand
}

Contact: michael.roy@gcu.ac.uk

Authors' pre-publication version. Cite as:

Roy MJ and Grant S (2019) The Contemporary Relevance of Karl Polanyi to Critical Social Enterprise Scholarship. Journal of Social Entrepreneurship. DOI: $\underline{10.1080 / 19420676.2019 .1621363 .}$. 


\begin{abstract}
The importance of the work of Karl Polanyi to social enterprise scholarship is often maintained. However, explanations as to how and why his ideas are so relevant to the field are still relatively scarce. In this essay we argue that engaging with Polanyi's work directly, and Polanyian scholarship more widely, can provide a deep understanding of the underlying assumptions within current social enterprise conceptualisations, and provide insights into how the relative positioning of market and society may be manipulated to maintain hegemonic positions. Three of Polanyi's key concepts are considered and discussed in turn: the 'substantive economy', the notion of 'embeddedness', and his 'double movement' thesis. The contemporary relevance of each concept, and the implications for future research, are presented and discussed, with a view to providing a platform from which to pursue a reinvigorated, emancipatory critical research agenda.
\end{abstract}

Key words: Social Enterprise, Polanyi, critical research 


\section{Introduction}

It is almost axiomatic to say that social enterprise scholarship has come to be dominated by a "neoliberal ideological climate that is characterised by a discourse of self-sufficiency and a belief in the virtue of markets" (Child, 2016: 218; see also Nicholls and Teasdale, 2017). While we continue to grapple with the consistently shifting roles of the state, market and civil society, and the role of social enterprise and social entrepreneurship within such discussions, there is a significant body of evidence to suggest that a highly dominant mode of thinking persists which seeks to 'celebrate' the actions of individual social entrepreneurs to instigate 'system-wide social change' (Drayton, 2011) or innovation for social purpose (Dees, 1998). This stance also appears within a context of little or no tradition of (nor, indeed, appetite for) examining the role of government in addressing entrenched social problems. Such uncritical support for marketbased approaches to addressing social issues (viz Gerrard, 2015), could be seen as problematic; not least for the principles of democracy and an active and engaged civil society (Dart, 2004b; Eikenberry and Kluver, 2004; Roy and Hackett, 2017; Sepulveda, 2015).

There is evidence, however, not least in this Journal, of a growing appetite for scholarship undertaken in a critical vein, particularly to act as a counterbalance to what might reasonably be labelled as the forces of 'market fundamentalism' (Block and Somers, 2014; Stiglitz, 2009). One of the most significant critics of market fundamentalism of the twentieth century was the Hungarian economic historian/anthropologist Karl Polanyi. Attention to Polanyi's works and ideas generally has increased exponentially since the Great Financial Crisis of 2008 (Somers and Block, 2014) and are regularly presented as having relevance to social enterprise scholarship (see, for example, Defourny et al., 2014; Nyssens, 2006; Ridley-Duff and Bull, 2015). Several mini conferences and streams in main conferences principally organised by the 
EMES $^{1}$ International Research Network, have been devoted to the application of his ideas. Polanyi's 'conceptual toolbox' has been said to provide the underpinning theoretical basis for certain conceptualisations of social enterprise, particularly those emanating from continental Europe (see, for example, Defourny and Nyssens, 2006; Gardin, 2014; Laville, 2014; Laville et al., 2006; Laville and Nyssens, 2001). But despite being regarded as "one of the most significant entry points for those social critics who are animated primarily by moral concern for the dispossessed and disempowered" (Lind, 1994: 143), the relevance of Karl Polanyi's work to the study of social enterprise has rarely been elaborated upon, nor advanced, in the social enterprise literature: there has been no rigorous attempt, at least until now, to demonstrate just how and why his ideas are so relevant and important to today.

Our essay attempts to fill this gap and is organised as follows: we begin by briefly locating our work within existing scholarship, with specific consideration of the developing critical research agenda for social enterprise. We draw upon Polanyi's work directly, and Polanyian scholarship more widely, to gain valuable insight into the market-dominant models of social enterprise frequently presented in scholarship. Three of Polanyi's key concepts are considered and discussed in turn: the 'substantive economy', the notion of 'embeddedness', and the 'double movement' thesis. The contemporary relevance of each concept, and the implications for each idea to critical social enterprise research, are presented and discussed. First of all, however, we turn our attention to a question: why do we need a critical research agenda for social enterprise at all?

\footnotetext{
${ }^{1}$ EMergence des Entreprises Sociales en Europe
} 


\section{The need for a critical research agenda}

Within many of the mainstream conceptualisations of social enterprise there is an implicit assumption that 'the market' - that is, the capitalist metaphor of the market - is a positive (or, at worst, neutral) force that can be readily and unproblematically harnessed for the common good of society. A critical analysis, such as within the spirit of the Frankfurt School (viz Adorno and Horkheimer, 1944; Horkheimer, 1975), questions "whose 'truth' is being perpetuated, privileged and positions in any particular context/s - and why?.... [Such] analysis is not about replacing one position with another but about questioning the very assumptions made" (Tedmanson et al., 2012: 537 - emphasis in original). Dominant paradigms can be challenged through the application of alternative theoretical lenses. A critical lens encourages us to question the unspoken assumptions that such dominant paradigms would have us take for granted.

A rich vein of critical social enterprise scholarship can be traced back well over a decade. Both Haugh (2005) and Peattie and Morley (2008) have provided seminal considerations, with the latter highlighting how paradoxical elements arising from the hybrid blend of social aspirations and enterprise/business practices have shaped our research focus. The concerns raised by both Dart (2004a) and Eikenberry and Kluver (2004) over the pressures and potential consequences of non-profit and voluntary sector organizations to become more 'business like' are also early examples of scholarly attention alerting researchers and practitioners to unintended outcomes. A natural progression of this research agenda - the formal inclusion of a critical lens - was advocated by Steyaert and Dey (2010) who encourage us to critique and intervene in practice, and processes and research thereof. In so doing, we are urged to recognise and appreciate the depth of multiple contexts and historical influences that shape not only the practice of social enterprise, but also our approach to its research. Teasdale (2012a: 88) exhorts us to recognise 
that "an uncritical stance may harm the development of the field of research and the organisations we sympathise with" while Dey and Steyaert (2012: 91) stress the necessity for critique, suggesting that critique is not an end in itself, but rather serves as a "means to creating things (both imaginative and real), which are not possible within the matrix of the present". It is helpful to recognise, however, that critique need not be negative (Grant, 2006, 2007) as evidenced by Curtis (2008) valuing weakness and failure within a social enterprise context and Ridley-Duff and Bull (2011: 45) associating critical social enterprise scholarship research with attempts to "secure emancipatory change by exposing political agendas implicit in scientific and management rhetoric". Parkinson and Howorth (2008) and, more recently, Dey and Teasdale, (2016), Nicholls and Teasdale (2017), Ruebottom (2018) and Dey and Mason (2018) have all provoked us to critically consider the underlying (neoliberal) discourses that have encouraged the proliferation of social enterprise policy and practice. Application of critical consideration to the field is, therefore, in keeping with our transformational aspirations.

The plurality of conceptualisations and practices (Defourny and Nyssens, 2010; Kerlin, 2009, 2013) and multiple lenses through which we might consider social enterprise activity provides multiple avenues for critical analysis. Critical consideration of all dimensions is essential if we are to advance both social enterprise practice and scholarship. Many aspects that we might consider are not, of course, unique to the field. For example, concerns over imbalances of power and hegemonic manifestations of market domination, particularly to the detriment of other aspects of society, are well documented in critiques of neoliberalism (Crouch, 2013; Harvey, 2007). The work of Polanyi, however, provides a conduit through which we might begin to bring these lines of critical consideration together. In doing so, we take existing applications of Polanyi's work in the community/social domain (e.g. Sheikheldin and Devlin, 2015) a step further into the complex sphere of social enterprise. 


\section{The contemporary relevance of Polanyi}

Originally published in 1944, Polanyi's seminal text The Great Transformation, provides an analysis of the century-long struggle between those who advocated for an unregulated laissezfaire market, and those who sought to protect society from the social upheaval, instability and inequality that a market economy inevitably causes (Block, 2003). By exploring attempts to protect society against the ravages of 'free market' dogma during the nineteenth century, Polanyi argues that the First World War, the Great Depression of the 1930s, and the emergence of fascism in Europe could all be traced back to the "utopian endeavour of economic liberalism to set up a self-regulating market system" (Polanyi, 1944: 31). He frames these events as manifestations of an underlying problem - the disruption of social unity - which itself was rooted in the rise of what he calls the 'market society': where markets come to dominate all aspects of our daily life. When production and distribution are entrusted to a "self-regulating market system" (Polanyi, 1944: 71) then 'self-regulation' implies that almost everything is for sale on the market and all incomes derive from such sales. This effectively translates into the existence of markets for trading of all elements of industry, so not only goods and services, but also other essential elements such as labour, land and money become tradable goods, a process Polanyi describes as "fictitious commodification" (Polanyi, 1944: 72; Fraser, 2014): fictitious because they are not 'created' as such for selling in the marketplace.

Polanyi demonstrates how the growth of the market society is dependent on the actions of the state in creating the social and legal frameworks that allow markets to operate 'freely': laissezfaire - he argues - is actually planned. He observes that, in reality, the market is not a 'free' and self-regulating entity but requires the provision of a set of institutional arrangements and social relationships in order to enable its apparently 'free' hand to work. Such manipulation not only involves regulations around what constitutes fair and free trade - the drafting and 
fulfilment of contracts, financial regulations, and so on - but also the involvement of the state in managing the supply of money and credit, as well as in developing a framework of rules and regulations regarding the provision of land and labour. In short, the socially constructed and increasingly reified market relies upon the state to provide the conditions that enable it to work.

We now turn attention to three of Polanyi's key concepts which, we propose, are particularly useful to advance a critical social enterprise research agenda: the 'substantive economy', 'embeddedness' and the 'double movement' thesis.

\section{The 'substantive economy'}

Polanyi does not deny the utility of markets for the allocation of some goods and services. What he condemns is the "quasi-religious certainty expressed by contemporary advocates of market self-regulation" (Block and Somers, 2014: 3). Polanyi critiques neo-classical economic theory for restricting focus on the 'formal' meaning of economics: focusing on choice, the means-end relationship, and the alleged scarcity of things. He also identifies a tendency in the study of economics to equate 'the economy' exclusively with the market, a representation he calls the 'economistic fallacy' (Polanyi, 1944: 270). Instead, Polanyi sees the market as "part of the broader economy, and the broader economy as part of a still broader society...the market economy not as an end in itself, but as a means to a more fundamental ends" (Stiglitz, 2001: $\mathrm{xv}$ ). Advancing a self-regulated market (or, rather, acting as if such a thing were possible) is ultimately damaging to society because it means that society inevitably ends up being treated as if it were an 'adjunct' or subordinate to the market, rather than the other way around.

To the formal concept of economics Polanyi counterposes a 'substantive' concept of economics (Hopkins, 1957; Polanyi, 1957) "grounded in reality and not in logic" (Swedberg, 2003: 28). He considers the economy, in its substantive sense, as "an instituted process of interaction 
between man and his environment, which results in a continuous supply of want-satisfying material means" (Polanyi, 1957: 243). He explains that Adam Smith's expression in The Wealth of Nations (Smith, 1976 [1776]: 17) regarding people's "propensity to barter, truck and exchange one thing for another" - the guiding principle of the Homo Economicus ${ }^{2}$ concept was actually a profound misreading of what happened in the past. Polanyi argues that all economic systems have always been organised, at least up until relatively recently in history, on the principle of reciprocity (commonly via household/community/civil society), redistribution (most commonly via the state), or on the principle of exchange (via the market), or some combination of all three. Polanyi's admiration for Smith is more apparent in an essay published posthumously in Primitive, Archaic and Modern Economies called 'The Place of Economies in Societies' (Polanyi, 1971). In contrast to how Smith's ideas, particularly in Wealth of Nations, have come to be misused to further the neoliberal project, Polanyi recognises that Smith saw the economy as very much part of society. Shaped by the rich moral and philosophical fabric revealed earlier in The Theory of Moral Sentiments (Smith, 2002 [1759]): "Adam Smith wished to discourage the idea that the self-interest of the merchant naturally benefited the community [...] Self-interest is not yet differentiated into economic motives of employers and employed. All through, the approach is still institutional, historical and societal" (Polanyi, 1971: 128-129).

By positing a substantivist approach to the economy, Polanyi thus presents economic life as a totality of relations and institutions that goes beyond transactions of goods and services

\footnotetext{
${ }^{2}$ See, for example, the paper by Coase (1976), which was initially presented at a meeting of the Mont Pelerin Society in St Andrews, Fife. The Mont Pelerin Society, of which (ironically) Polanyi's brother Michael was a founding member, was established in 1947 by a group of prominent intellectuals and business leaders committed to the political project of returning economic liberalism to the forefront (hence 'neoliberalism') at a time when Keynesianism was dominant.
} 
(Polanyi, 1971; Block and Somers, 1984; Granovetter and Swedberg, 2001; Smelser and Swedberg, 2005). Such a classification of the different societal arrangements by which the range of human economies organise themselves allows the apprehension of "an institutionalized pattern of relationships by which individual social units are linked together to form a social whole" (Block and Somers, 2014: 66). Bruni and Zamagni observe that these 'three pillars' (Mendell, 2009) are distinct but not independent, and argue that 'if this 'triadic' structure is sustained - if all three of these principles are active and well-combined - then societies develop in a harmonious way" (Bruni and Zamagni 2007: 19). This 'three pillared' principle has influenced the conceptualisation of social enterprise put forward by those close to EMES. Defourny and Nyssens (2006: 10-11), for example, recognise the fundamental importance of substantivist thinking to social enterprise research by explaining that social enterprises "hybridize these three types of economic exchange so that they work together rather than in isolation from each other." Defourny and Nyssens (2006: 13) further explain that "Social enterprises mix different logics: they trade in the market, but not with an aim of maximising the financial return on investment for their shareholders; they receive public support through public policies which they contribute to shaping; they are embedded in civil society through the development of voluntary collective action around common goals characterized by a public benefit dimension.”

The ability to combine the various Polanyian economic principles is the 'essence' of social enterprise in this conceptualisation. It is what sets social enterprises apart from the traditional voluntary sector, the public sector and the mainstream for-profit sector. However, this conceptualisation of 'hybridity' of principles - 'Polanyian Hybridity' if you like - needs to be distinguished from alternative conceptualisations of hybridity commonly applied in approaches to conceptualising social enterprise, the most common of which is a form of the social- 
economic dyadic. Scholars and practitioners often portray the social enterprise as a 'hybrid' organizational form (Battilana and Lee, 2014; Besharov and Smith, 2014; Doherty et al., 2014) which break new ground between the traditional private, public and non-profit sectors, and thus pose challenges to classical understandings of organizational behaviour and theory. Hybrids span institutional boundaries (Brandsen and Karré, 2011; Tracey et al., 2011) and give rise to conflicting institutional logics (Pache and Santos, 2013). However, while such research has been instrumental in driving our field forward and establishing a theoretical basis for social enterprise as a distinct organizational form, there are inherent dangers in utilizing such concepts for the foundation of our studies if we adopt too narrow a perspective on what we conceive as 'the economy' or that economy and society are separate (or 'disembedded') from each other. One consequence of such a limited perspective is that, particularly in early scholarship, social enterprises have tended to be defined by their position on a continuum, spanning from the 'purely charitable/philanthropic' (or 'social') to the 'purely commercial' (or 'economic') (see Alter, 2007; Dees and Anderson, 2006: 51) as seen along the lines presented in Figure 1.

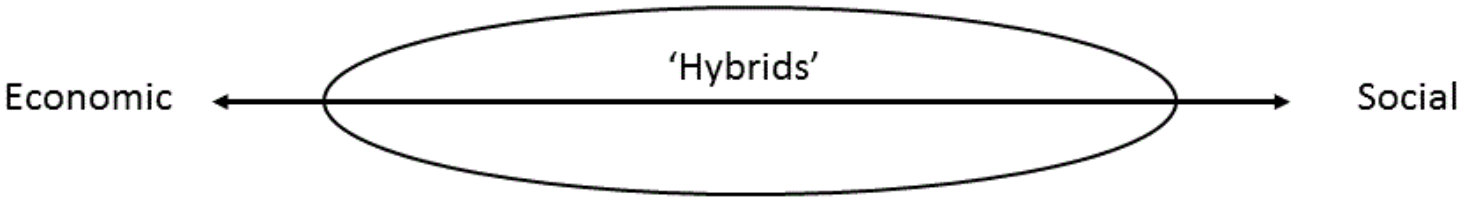

Figure 1: Common perspectives on hybridity

Such a continuum, or one like it, has provided a foundation for a considerable body of influential social enterprise scholarship to date (see for example, Alter, 2007; Dees and Anderson, 2006; Dees and Elias, 1998). But unquestioningly accepting the assumption that the social-economic relationship is dyadic, we would argue, potentially narrows our focal lens and 
reinforces neoliberal assertions about the dichotomy between economy and society. We have to recognise that social enterprise is a highly 'fluid and contested' concept (Teasdale, 2012c), shaped (among many factors) by context, sector, culture, region, culture, politics, history, geography, ideology (or even 'moral sentiment' to evoke Smith again). In essence, a social enterprise based in Nairobi is unlikely to resemble a social enterprise based in Northampton except in the most superficial ways. A discussion on the Polanyian concept of embeddedness helps us to elaborate on this point further.

\section{(Polanyian) Embeddedness}

Polanyi argues that

'[t]he human economy...is embedded and enmeshed in institutions, economic and noneconomic. The inclusion of the noneconomic is vital. For religion or government may be as important for the structure and functioning of the economy as monetary institutions or the availability of tools and machines themselves that lighten the toil of labor" (Polanyi, 1957: 250).

The fullest elaboration of Polanyi's notion of embeddedness is not to be found in The Great Transformation but in Trade and Market in the Early Empires (1957) and most especially in his essay 'The Economy as Instituted Process' (Polanyi, 1957). Without state intervention and being embedded in social communities supposedly 'free' markets cannot survive. Furthermore, they cannot - at least by themselves - provide social necessities such as education, health care, social and personal security, and the right to earn a livelihood. When certain goods and services, such as public goods, are subjected to market principles, social life is threatened and major crises can ensue (Hodgson, 2017; Polanyi Levitt, 2013). 
The concept of 'embeddedness' has, of course, been a principal feature of organizational scholarship over the last 30 years (Jack and Anderson, 2002), including within social enterprise and social entrepreneurship literature (Dufays and Huybrechts, 2014). But such scholarship has, in the main, been guided by the seminal work of Granovetter (1985) and the way in which Polanyi employs the term is not, strictly speaking, the same way that it was initially employed by Granovetter and those who have followed since (for a full discussion see Krippner, 2002; Krippner et al., 2004; Krippner and Alvarez, 2007; Machado, 2011). To do justice to the history of the concept of embeddedness, which has undergone something of a 'great transformation' of its own, as Beckert (2011) aptly suggests, is well beyond the scope of this paper. However, in her own engagement with Polanyi's work, Peredo (2012: 102) identifies that Polanyi referred to a 'deeper' sense of embeddedness than Granovetter imagined, where economic transactions are

"generally undertaken in the context of a web of reciprocal obligations and understandings and/or acceptance of redistributive rights of community authority. They were not determined by market prices or expectations of individual gain, but by notions of community benefit, and one's place in realizing that."

Child (2016) begins to consider the impact of embeddedness, but does not explicitly engage with the work of Polanyi. Drawing on examples of fair trade and socially responsible investment, though, he demonstrates how market-based initiatives rely on social movements and non-profit organisations as part of their success. In their paper on embeddedness, Seelos et al. (2011) also do not mention Polanyi explicitly, but talk of a number of 'institutional mechanisms' which stem from the community, such as 'regulative, normative and cognitive forces' which influence the emergence of socially entrepreneurial organizations. 
Beckert (2010), meanwhile, reminds us that markets themselves are shaped by social forces and 'market actors' expectations are formed by the structural, institutional and cultural embeddedness of market exchange" (Beckert, 2009: 247). He identifies three separate aspects that are relevant in explaining economic outcomes: social networks, institutions, and cognitive frames. Understanding the dynamic interaction between these forces, he argues, is vital to an appreciation and understanding of how society shapes markets, and vice versa (see also Nicholls and Ziegler, 2017).

By following a Polanyian conceptualisation of 'the economy', and moving away from a social - economic dyadic, we can consider the economic activity of social enterprises (in a substantive sense) as the means by which they achieve their ends (viz Kay et al., 2016) i.e. fulfilment of their social mission, as shown in Figure 2. In this conceptualisation there is no 'hybridity of purpose': the aims or purposes of the economic activity, and the process by which they achieve their means, are clearly on different 'axes' or conceptual levels.

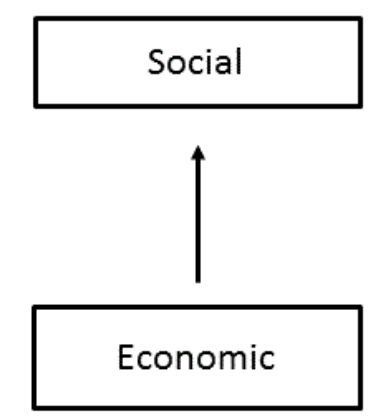

Figure 2: Economic 'means' and social 'ends'

This reconfiguration is presented not to obfuscate tensions, nor to pretend that tensions between social and commercial considerations do not exist: of course they do. But what is of interest to us is how scholars understand, and potentially work with (or against) such tensions, and to 
reveal and focus attention on 'means' and 'ends' to understand, and even combat, tendencies such as 'mission drift' (Cornforth, 2014). Both Bull (2008) and Teasdale (2012b) suggest that it is incumbent upon those interested in pursuing a critical research agenda for social enterprise to keep in mind that the tension between the notions of 'social' and 'enterprise' is an inherently problematic one. Grant (2014), meanwhile, suggests that much of the unique value in social enterprise resides in this tension; that without this tenuous balance an organisation would simply be a non-profit or for-profit organisation. Our intention here is to provoke scholars to reflexively (re-)consider the preconceived assumptions that influence our research: for example, when means and ends are set up as oppositional, is this, in fact, presenting a form of false dichotomy that works to restrict our thinking (and practice), and, indeed, to further the 'disembedding' of economy from society?

\section{The 'double movement'}

The concept of the 'double movement' refers to the process by which society is compelled to protect itself from the social disintegration that, Polanyi shows, occurs as an inevitable consequence of the commodification of land, labour and money (Dale, 2016; Goodwin, 2018). Polanyi observes that, at key points in history, political parties and social movements tend to coalesce around either side of a fault line, with those favouring deregulating markets and extending commodification on the one side and a "broad-based, cross-class front, including

urban workers and rural landowners, socialists and conservatives [seeking] to 'protect society' from the ravages of the market" (Fraser, 2013: 120) on the other. In Polanyi's time those on the side of 'social protection' won the day (the Great Transformation to which he refers), and so we saw New Deal America, the rise of post-war social democracies, Keynesian demand management, new social movements, and the development of new welfare states. 
But two decades now into the twenty-first century, we have seen a constant incremental erosion of the types of safety net that were beginning to be put into place when Polanyi was writing The Great Transformation; an erosion that has accelerated since the Great Financial Crisis, the implementation of public sector austerity, and the subsequent rise in populist policies and politicians (Mouffe, 2018). Capitalism itself, however, has emerged almost remarkably unscathed, if not stronger than before the Great Financial Crisis (Crouch, 2011). Indeed, Schram (2015) calls this present time simply the return of 'ordinary capitalism'; the bleak situation that Polanyi was hopeful that we had emerged from when he was writing in the 1940s. Polanyi's concept of the 'double movement' prompts us to consider whether activities such as social enterprise and social entrepreneurship can be considered as arising from, and mobilizing in direct response to, the dehumanizing effects of market fundamentalism. One of the driving motivations for social enterprise is dissatisfaction with the idea that the market is the source of all well-being, and that perpetual economic growth is not only possible, but that it can solve virtually every problem from hunger and poverty to environmental devastation. Yunus (2010), for instance, prefaces his argument for social business with the failure of the free market to solve global poverty and distribute wealth more equally and calls for a new type of capitalism to solve society's most pressing needs. Ridley-Duff and Bull (2011: 100) argue that "social enterprises offer either a partial or a complete rejection of established rules of international capitalism" and rejection of established 'rules and norms' is certainly the position of many contemporary debates on the potential of the 'social and solidarity economy' as an alternative system to that of international, globalised capitalism (Amin, 2009; Gardin, 2014; Utting, 2015). Indeed, Baum (1996) has long argued that we should look to Polanyi's understanding of modern capitalism to reinstate a 'social discourse' and the principles of reciprocity and solidarity. But one key challenge for the field, in presenting a viable alternative, is that much will depend upon 
what we actually mean when we talk of a 'social enterprise'. For example, one dominant conceptualisation relates to the purpose or sector of the activity, generally relating to the social sector such as day-care, health, elderly, or a specific social problem; that is, a 'social purpose' enterprise. Within this approach "the social has tended to refer to external purpose rather than internal dynamics, that is, what an organisation does rather than how it does it" (Teasdale, 2012c: 103). Often this approach, it could reasonably be argued, involves little more than the application of established strategic approaches from the commercial world to social problems (Nicholls and Young, 2008) and so a key concern in much of the emerging critical social enterprise literature remains: why are we perpetuating the belief that markets are unquestionably best placed to tackle intractable social and environmental problems, when these same mechanisms have been shown to exacerbate the very inequality that helps 'feed' these problems? (Humphries and Grant, 2005). Hjorth (2013:36-37) argues that the 'social' in social enterprise is weakened and made subordinate when the role of the market is emphasised above the other domains. Such a 'capitalocentric' view is particularly questionable when one considers the inherent paradox put forward: that the single best way of solving the ills of the market is through the market (Gibson-Graham, 2006).

It could be argued, too, that the idea of promoting the ability of business-savvy individual entrepreneurs to solve social problems with market-based innovations redirects us away from the structural causes of such problems. A Polanyian lens would argue that too firm a market focus for social enterprise risks exacerbating the disembedding of market from society: arguably the cause of many of the very social problems that social enterprises exist to address. The social inequalities and vulnerabilities of the forms that social entrepreneurs often focus their activities towards addressing (for example poverty or social exclusion) may increase or, at the very least, remain stubbornly resistant to positive change without radical, structural 
adjustments higher 'upstream'. Action, in other words, of the form that governments are often elected to make. Thus, while the public appeal of social enterprise and social entrepreneurship may be a response to the social failures of a market society, as Polanyi might predict, dominant approaches to scholarship are, arguably, a co-option of this 'countermovement'.

\section{Conclusion}

The application of a Polanyian lens allows insight into how elite actors, through entities such as neoliberal states and institutions, may manipulate the relative positioning of market and society in order to maintain their hegemonic positions. We have discussed how Polanyi's conceptualisation of embeddedness helps us to unpack inherent assumptions and normative influences concerning the primacy of market mechanisms. Such influences can be wide reaching, including within government policy. A rich vein of scholarship has revealed how governments have promoted social enterprise practices in organizations that provide social goods: effectively using the concept to further marketize the non-profit and voluntary sectors, while simultaneously diminishing government responsibility for the delivery of public social services. But promoting the encroachment of market ideals into non-profit and voluntary organizations, as Eikenberry and Kluver (2004) point out, can potentially place the important role of civil society at risk; in particular, their role as acting as a counterbalance to the worst excesses of the market and/or state: that is, their ability to act as a Polanyian countermovement. While it could be recognised that social enterprise and social entrepreneurship have arisen as a consequence of the rise of the neoliberal paradigm (or at least been co-opted to suit the aims of powerful actors to suit neoliberal ends), one interesting and fruitful line of research may be through the heuristic of the Polanyian 'double movement'. Through this lens we can examine the extent to which social enterprise activity, perhaps in combination with complementary social movements, are in a position to enact or exercise resistance or challenge the political 
economic status quo. Even incremental and/or small-scale transformation on the fringes of contemporary capitalism can begin to sow the seeds of change.

But Polanyi's ideas also invite us to go further and move beyond the confines of 'capitalocentrism': the idea that all forms of cultural practice, all forms of political economy, and all sites of socio-political activity are overwhelmed by, or subsumed into, the dynamics of capitalism, with no space left for alternatives (Hesketh, 2016). Gibson-Graham (2006: 106) warn us that reductive forms of thinking can foreclose the possibility of alternatives. But we know that alternative, non-capitalist economic spaces, including in the form of social enterprise, do exist (Amin et al., 2003; Baum, 2009). Polanyi provides us with a conceptual toolkit by which such organizations may start to be understood on their own terms; perhaps the very definition of a critical, emancipatory SE project.

Finally, we consider that a deeper understanding of the underlying assumptions within current social enterprise practices may be achieved through engaging with Polanyi's work directly, and with Polanyian scholarship more widely. Polanyi's concepts of substantivism and embeddedness in particular show us how applications of the economy-social continuum could potentially - albeit inadvertently - be reinforcing neoliberal assumptions about the separation of economy and society, or, at the very least, resist challenges to the very structures that have created many of the problems that they purport to wish to solve. Polanyian embeddedness encourages us to think more imaginatively: beyond, for example, the role of social networks to the 'success' or otherwise of socially entrepreneurial organisations. But the concept of embeddedness also helps us to conceptualise how powerful neoliberal actors can use the idea of social enterprise and social entrepreneurship to further promote the primacy of the market. Neoliberal concepts, and the accompanying rhetoric of self-interest and individualism has become a shaping paradigm of our everyday lives (Boltanski and Chiapello, 2007; Peck, 2012) 
but that should not prevent us from questioning the uncritical acceptance of the market system to provide solutions, given that many of the 'problems' that social enterprises seek to address arguably stem from the inequalities that an overemphasis upon markets inevitably creates. That said, much of the most recent research on the topic of organisational hybridity (including by the likes of Battilana et al., 2014; Castellas et al., 2018; Folmer and Stephan, 2016; Hockerts, 2015; Huybrechts and Haugh, 2018; Mair et al., 2015) encourages us to note that a simplistic dyadic 'opposition' between economy and society is becoming less and less obvious. We maintain, though, that the notion of 'Polanyian hybridity' may well add value to such conversations but we should also fully recognise that partly in a response to critiques of social enterprise and its increasing institutionalisation in the market, much work is now focusing on social innovation and systems innovation rather than social enterprise per se (Nicholls and Ziegler, 2017).

The world has changed markedly since Polanyi's time, but his ideas remain relevant. The application of Polanyi's ideas to the 'reality of society' (Somers, 2018) today can help guide our generative process and paradigms as we shape the economic and democratic organizations and institutions of the twenty-first century. 


\section{References}

Adorno TW and Horkheimer M (1944) Dialectic of Enlightenment. Verso Edition published in 1997. London: Verso Classics.

Alter SK (2007) Social Enterprise Typology. Virtue Ventures LLC. Available at: https://www.globalcube.net/clients/philippson/content/medias/download/SE_typology .pdf (accessed 30 April 2019).

Amin A (ed.) (2009) The Social Economy: International Perspectives on Economic Solidarity. London: Zed Books.

Amin A, Cameron A and Hudson R (2003) The Alterity of the Social Economy. In: Leyshon A, Lee R, and Williams CC (eds) Alternative Economic Spaces. Thousand Oaks, CA: SAGE Publications Ltd, pp. 27-54.

Battilana J and Lee M (2014) Advancing Research on Hybrid Organizing - Insights from the Study of Social Enterprises. The Academy of Management Annals 8(1): 397-441.

DOI: $10.1080 / 19416520.2014 .893615$.

Battilana J, Sengul M, Pache A-C, et al. (2014) Harnessing Productive Tensions in Hybrid Organizations: The Case of Work Integration Social Enterprises. Academy of Management Journal 58(6): 1658-1685. DOI: 10.5465/amj.2013.0903.

Baum G (1996) Karl Polanyi on Ethics and Economics. Montreal: McGill Queens University Press.

Baum G (2009) The Social Economy: An Alternative Model of Economic Development. Journal of Catholic Social Thought 6(1): 253-262.

Beckert J (2009) The Social Order of Markets. Theory and Society 38(3): 245-269. DOI: $10.1007 / \mathrm{s} 11186-008-9082-0$.

Beckert J (2010) How Do Fields Change? The Interrelations of Institutions, Networks, and Cognition in the Dynamics of Markets. Organization Studies 31(5): 605-627. DOI: $10.1177 / 0170840610372184$.

Beckert J (2011) The Great Transformation of Embeddedness: Karl Polanyi and the New Economic Sociology. In: Hann C and Hart K (eds) Market and Society: The Great Transformation Today. Cambridge: Cambridge University Press, pp. 38-55.

Besharov ML and Smith WK (2014) Multiple Institutional Logics in Organizations: Explaining Their Varied Nature and Implications. Academy of Management Review 39(3): 364-381. DOI: 10.5465/amr.2011.0431.

Block FL (2003) Karl Polanyi and the Writing of the Great Transformation. Theory and Society 32(3): 275-306. 
Block FL and Somers MR (1984) Beyond the Economistic Fallacy: The Holistic Social Science of Karl Polanyi. In: Skocpol T (ed.) Vision and Method in Historical Sociology. Cambridge: Cambridge University Press, pp. 47-61.

Block FL and Somers MR (2014) The Power of Market Fundamentalism: Karl Polanyi's Critique. Cambridge, MA: Harvard University Press.

Boltanski L and Chiapello E (2007) The New Spirit of Capitalism. London: Verso.

Brandsen T and Karré PM (2011) Hybrid Organizations: No Cause for Concern? International Journal of Public Administration 34(13): 827-836.

Bruni L and Zamagni S (2007) Civil Economy: Efficiency, Equity, Public Happiness. Frontiers of Business Ethics. Bern: Peter Lang.

Bull M (2008) Challenging Tensions: Critical, Theoretical and Empirical Perspectives on Social Enterprise. International Journal of Entrepreneurial Behaviour \& Research 14(5): 268-275.

Castellas EI, Stubbs W and Ambrosini V (2018) Responding to Value Pluralism in Hybrid Organizations. Journal of Business Ethics. DOI: 10.1007/s10551-018-3809-2.

Child C (2016) Tip of the Iceberg: The Nonprofit Underpinnings of For-Profit Social Enterprise. Nonprofit and Voluntary Sector Quarterly 45(2): 217-237.

Coase R (1976) Adam Smith's View of Man. The Journal of Law and Economics 19(3).

Cornforth C (2014) Understanding and Combating Mission Drift in Social Enterprises. Social Enterprise Journal 10(1): 3-20. DOI: 10.1108/SEJ-09-2013-0036.

Crouch C (2011) The Strange Non-Death of Neoliberalism. Cambridge: Polity Press.

Crouch C (2013) Making Capitalism Fit for Society. Cambridge: Polity Press.

Curtis T (2008) Finding That Grit Makes a Pearl: A Critical Re-Reading of Research into Social Enterprise. International Journal of Entrepreneurial Behaviour \& Research 14(5): 276-290.

Dale G (2016) Reconstructing Karl Polanyi. London: Pluto Press.

Dart R (2004a) Being "Business-Like" in a Nonprofit Organization: A Grounded and Inductive Typology. Nonprofit and Voluntary Sector Quarterly 33(2): 290-310.

Dart R (2004b) The Legitimacy of Social Enterprise. Nonprofit Management and Leadership 14(4): 411-424.

Dees JG (1998) The Meaning of Social Entrepreneurship. Duke University - Fuqua School of Business. Available at: https://csistg.gsb.stanford.edu/sites/csi.gsb.stanford.edu/files/TheMeaningofsocialEntr epreneurship.pdf (accessed 4 September 2018). 
Dees JG and Anderson BB (2006) Framing a Theory of Social Entrepreneurship: Building on Two Schools of Practice and Thought. In: Mosher-Williams R (ed.) Research on Social Entrepreneurship: Understanding and Contributing to an Emerging Field. ARNOVA Occasional Paper Series, 1(3), pp. 39-66.

Dees JG and Elias J (1998) Review: The Challenges of Combining Social and Commercial Enterprise. Business Ethics Quarterly 8(1): 165-178. DOI: 10.2307/3857527.

Defourny J and Nyssens M (2006) Defining Social Enterprise. In: Nyssens M (ed.) Social Enterprise: At the Crossroads of Market, Public Policies and Civil Society. Routledge Series in the Management of Voluntary and Non-Profit Organizations. Abingdon, Oxon: Routledge, pp. 3-26.

Defourny J and Nyssens M (2010) Conceptions of Social Enterprise and Social Entrepreneurship in Europe and the United States: Convergences and Divergences. Journal of Social Entrepreneurship 1(1): 32-53.

Defourny J, Hulgård L and Pestoff V (eds) (2014) Social Enterprise and the Third Sector: Changing European Landscapes in a Comparative Perspective. Abingdon, Oxon: Routledge.

Dey P and Mason C (2018) Overcoming Constraints of Collective Imagination: An Inquiry into Activist Entrepreneuring, Disruptive Truth-Telling and the Creation of 'Possible Worlds'. Journal of Business Venturing 33(1): 84-99. DOI: 10.1016/j.jbusvent.2017.11.002.

Dey P and Steyaert C (2012) Social Entrepreneurship: Critique and the Radical Enactment of the Social. Social Enterprise Journal 8(2): 90-107.

Dey P and Teasdale S (2016) The Tactical Mimicry of Social Enterprise Strategies: Acting 'As If' in the Everyday Life of Third Sector Organizations. Organization 23(4): 485504. DOI: $10.1177 / 1350508415570689$.

Doherty B, Haugh H and Lyon F (2014) Social Enterprises as Hybrid Organizations: A Review and Research Agenda. International Journal of Management Reviews 16(4): 417-436. DOI: 10.1111/ijmr.12028.

Drayton W (2011) Everyone a Changemaker - Social Entrepeneurship's Ultimate Goal. In: Petit PU (ed.) Creating a New Civilization Through Social Entrepreneurship. Piscataway, NJ: First Transaction Publishers/Goi Peace Foundation, pp. 53-62.

Dufays F and Huybrechts B (2014) Connecting the Dots for Social Value: A Review on Social Networks and Social Entrepreneurship. Journal of Social Entrepreneurship 5(2): 214-237. DOI: 10.1080/19420676.2014.918052.

Eikenberry AM and Kluver JD (2004) The Marketization of the Nonprofit Sector: Civil Society at Risk? Public Administration Review 64(2): 132-140. 
Folmer EC and Stephan U (2016) Bringing the State back in: How Hybrid Organizations Navigate Plurality in Institutional Environments. Academy of Management Proceedings 2016(1): 12289. DOI: 10.5465/ambpp.2016.12289abstract.

Fraser N (2013) A Triple Movement?: Parsing the Politics of Crisis After Polanyi. New Left Review (81): 119-132.

Fraser N (2014) Can Society Be Commodities All the Way down? Post-Polanyian Reflections on Capitalist Crisis. Economy and Society: 1-18. DOI: 10.1080/03085147.2014.898822.

Gardin L (2014) Solidarity Based Initiatives: Field Realities and Analysis. In: Defourny J, Hulgård L, and Pestoff V (eds) Social Enterprise and the Third Sector: Changing European Landscapes in a Comparative Perspective. Abingdon, Oxon: Routledge, pp. 114-129.

Gerrard J (2015) Welfare Rights, Self-Help and Social Enterprise: Unpicking Neoliberalism's Mess. Journal of Sociology: 1-16. DOI: 10.1177/1440783315607388.

Gibson-Graham JK (2006) A Postcapitalist Politics. Minneapolis: University of Minnesota Press.

Goodwin G (2018) Rethinking the Double Movement: Expanding the Frontiers of Polanyian Analysis in the Global South. Development and Change 49(5): 1268-1290. DOI: 10.1111/dech.12419.

Granovetter M (1985) Economic Action and Social Structure: The Problem of Embeddedness. American Journal of Sociology 91(3): 481-510.

Granovetter MS and Swedberg R (eds) (2001) The Sociology of Economic Life. 2nd ed. Boulder, CO: Westview Press.

Grant S (2006) Community (Not-for-Profit) Governance - What Are Some of the Issues? Third Sector Review 12(1): 39-56.

Grant S (2007) Learning Through 'Being' and 'Doing'. Action Research 5(3): 265-274. DOI: $10.1177 / 1476750307081017$.

Grant S (2014) Social Enterprise Through a Critical Appreciative Lens. In: Denny S and Seddon F (eds) Social Enterprise: Accountability and Evaluation around the World. Abingdon, Oxon: Routledge, pp. 213-231.

Harvey D (2007) A Brief History of Neoliberalism. Oxford: Oxford University Press.

Haugh H (2005) A Research Agenda for Social Entrepreneurship. Social Enterprise Journal 1(1): 1-12. DOI: 10.1108/17508610580000703.

Hesketh C (2016) The Survival of Non-Capitalism. Environment and Planning D: Society and Space. DOI: 10.1177/0263775816639313. 
Hjorth D (2013) Public Entrepreneurship: Desiring Social Change, Creating Sociality. Entrepreneurship \& Regional Development 25(1-2): 34-51.

Hockerts K (2015) How Hybrid Organizations Turn Antagonistic Assets into Complementarities. California Management Review 57(3): 83-106. DOI: 10.1525/cmr.2015.57.3.83.

Hodgson GM (2017) Karl Polanyi on Economy and Society: A Critical Analysis of Core Concepts. Review of Social Economy 75(1): 1-25. DOI: 10.1080/00346764.2016.1171385.

Hopkins TK (1957) Sociology and the Substantive View of the Economy. In: Polanyi K, Arensberg CM, and Pearson HW (eds) Trade and Market in the Early Empires: Economies in History and Theory. Glencoe, IL: Free Press, pp. 270-306.

Horkheimer M (1975) Critical Theory: Selected Essays. New York: Continuum.

Humphries M and Grant S (2005) Social Enterprise and Re-Civilization of Human Endeavors: Re-Socializing the Market Metaphor or Encroaching Colonization of the Lifeworld? Current Issues in Comparative Education 8(1): 41-50.

Huybrechts B and Haugh H (2018) The Roles of Networks in Institutionalizing New Hybrid Organizational Forms: Insights from the European Renewable Energy Cooperative Network. Organization Studies 39(8): 1085-1108. DOI: 10.1177/0170840617717097.

Jack SL and Anderson A (2002) The Effects of Embeddedness on the Entrepreneurial Process. Journal of Business Venturing 17(5): 467-487.

Kay A, Roy MJ and Donaldson C (2016) Re-Imagining Social Enterprise. Social Enterprise Journal 12(2): 217-234. DOI: 10.1108/SEJ-05-2016-0018.

Kerlin JA (ed.) (2009) Social Enterprise: A Global Comparison. Lebanon, NH: University Press of New England.

Kerlin JA (2013) Defining Social Enterprise Across Different Contexts: A Conceptual Framework Based on Institutional Factors. Nonprofit and Voluntary Sector Quarterly 42(1): 84-108. DOI: 10.1177/0899764011433040.

Krippner GR (2002) The Elusive Market: Embeddedness and the Paradigm of Economic Sociology. Theory and Society 30(6): 775-810.

Krippner GR and Alvarez AS (2007) Embeddedness and the Intellectual Projects of Economic Sociology. Annual Review of Sociology 33(1): 219-240. DOI: 10.1146/annurev.soc.33.040406.131647.

Krippner GR, Granovetter M, Block FL, et al. (2004) Polanyi Symposium: A Conversation on Embeddedness. Socio-Economic Review 2: 109-135. 
Laville J-L (2014) The Social and Solidarity Economy: A Theoretical and Plural Framework. In: Defourny J, Hulgård L, and Pestoff V (eds) Social Enterprise and the Third Sector: Changing European Landscapes in a Comparative Perspective. Abingdon, Oxon: Routledge, pp. 102-113.

Laville J-L and Nyssens M (2001) The Social Enterprise: Towards a Theoretical SocioEconomic approach. In: Borzaga $\mathrm{C}$ and Defourny $\mathrm{J}$ (eds) The Emergence of Social Enterprise. London: Routledge, pp. 312-332.

Laville J-L, Lemaitre A and Nyssens M (2006) Public Policies and WISEs in Europe. In: Nyssens M (ed.) Social Enterprise: At the Crossroads of Market, Public Policies and Civil Society. Abingdon, Oxon: Routledge, pp. 272-295.

Lind C (1994) How Karl Polanyi’s Moral Economy Can Help Religious and Other Social Critics. In: McRobbie K (ed.) Humanity, Society and Commitment: On Karl Polanyi. Critical Perspectives on Historic Issues. Montréal: Black Rose Books, pp. 143-161.

Machado NMC (2011) Karl Polanyi and the New Economic Sociology: Notes on the Concept of (Dis)embeddedness. RCCS Annual Review. a Selection from the Portuguese Journal Revista Crítica De Ciências Sociais (3). Available at: http://rccsar.revues.org/309 (accessed 29 March 2019).

Mair J, Mayer J and Lutz E (2015) Navigating Institutional Plurality: Organizational Governance in Hybrid Organizations. Organization Studies 36(6): 713-739. DOI: $10.1177 / 0170840615580007$.

Mendell M (2009) Three Pillars of the Social Economy. In: Amin A (ed.) The Social Economy: International Perspectives on Economic Solidarity. London; New York: Zed Books, pp. 176-207.

Mouffe C (2018) Populists Are on the Rise but This Can Be a Moment for Progressives Too. The Guardian, 10 September. Available at:

https://www.theguardian.com/commentisfree/2018/sep/10/populists-rise-progressivesradical-right (accessed 18 October 2018).

Nicholls A and Teasdale S (2017) Neoliberalism by Stealth? Exploring Continuity and Change Within the UK Social Enterprise Policy Paradigm. Policy \& Politics 45(3): 323-341(19). DOI: http://dx.doi.org/10.1332/030557316X14775864546490.

Nicholls A and Young R (2008) Preface. In: Nicholls A (ed.) Social Entrepreneurship: New Models of Sustainable Social Change. Oxford: Oxford University Press.

Nicholls A and Ziegler R (2017) An Extended Social Grid Model for the Study of Marginalization Processes and Social Innovation. CRESSI Working Paper 2/2015 (revised 4/2017). Available at: http://eureka.sbs.ox.ac.uk/5947/1/CRESSI_Working_Paper_2_2017rev_Chp2_April1 7.pdf. 
Nyssens M (ed.) (2006) Social Enterprise: At the Crossroads of Market, Public Policies and Civil Society. Abingdon, Oxon: Routledge.

Pache A-C and Santos F (2013) Inside the Hybrid Organization: Selective Coupling as a Response to Competing Institutional Logics. Academy of Management Journal 56(4): 972-1001. DOI: 10.5465/amj.2011.0405.

Parkinson C and Howorth C (2008) The Language of Social Entrepreneurs. Entrepreneurship and Regional Development 20(3): 285-309. DOI: http://dx.doi.org/10.1080/08985620701800507.

Peattie K and Morley A (2008) Eight Paradoxes of the Social Enterprise Research Agenda. Social Enterprise Journal 4(2): 91-107.

Peck J (2012) Constructions of Neoliberal Reason. Oxford: Oxford University Press.

Peredo AM (2012) The Difference Culture Makes: The Competitive Advantage of Reciprocal, Non-Monetary Exchange. In: Quarter J, Mook L, and Ryan S (eds) Businesses with a Difference: Balancing the Social and the Economic. University of Toronto Press, pp. 87-110.

Polanyi K (1944) The Great Transformation: The Political and Economic Origins of Our Time. Second Beacon Paperback Edition Published in 2001. Boston, MA: Beacon Press.

Polanyi K (1957) The Economy as Instituted Process. In: Polanyi K, Arensberg CM, and Pearson HW (eds) Trade and Market in the Early Empires: Economies in History and Theory. Glencoe, IL: Free Press, pp. 243-269.

Polanyi K (1971) Primitive, Archaic, and Modern Economies: Essays of Karl Polanyi. Dalton G (ed.). Boston: Beacon Press.

Polanyi Levitt K (2013) From the Great Transformation to the Great Financialization: On Karl Polanyi and Other Essays. London; New York: Zed Books.

Ridley-Duff R and Bull M (2011) Understanding Social Enterprise: Theory \& Practice. London: SAGE.

Ridley-Duff R and Bull M (2015) Understanding Social Enterprise: Theory and Practice. 2nd ed. London: SAGE Publications.

Roy MJ and Hackett MT (2017) Polanyi's 'Substantive Approach' to the Economy in Action? Conceptualising Social Enterprise as a Public Health 'Intervention'. Review of Social Economy 75(2): 89-111. DOI: 10.1080/00346764.2016.1171383.

Ruebottom T (2018) Deliberative Democracy in Social Entrepreneurship: A Discourse Ethics Approach to Participative Processes of Social Change. In: Dey P and Steyaert C (eds) Social Entrepreneurship: An Affirmative Critique. Cheltenham: Edward Elgar Publishing Limited, pp. 191-209. 
Schram SF (2015) The Return of Ordinary Capitalism: Neoliberalism, Precarity, Occupy. Oxford; New York: OUP USA.

Seelos C, Mair J, Battilana J, et al. (2011) The Embeddedness of Social Entrepreneurship: Understanding Variation Across Local Communities. In: Marquis C, Lounsbury M, and Greenwood R (eds) Communities and Organizations. Research in the Sociology of Organizations. Bingley: Emerald, pp. 333-363.

Sepulveda L (2015) Social Enterprise - a New Phenomenon in the Field of Economic and Social Welfare? Social Policy \& Administration 49(7): 842-861. DOI: 10.1111/spol.12106.

Sheikheldin GH and Devlin JF (2015) Community Development as Double Movement. International Journal of Community Development 3(1): 1-19.

Smelser NJ and Swedberg R (2005) The Handbook of Economic Sociology. 2nd ed. Princeton, NJ: Princeton University Press.

Smith A (1976) An Inquiry into the Nature and Causes of the Wealth of Nations. The Glasgow edition of the works and correspondence of Adam Smith. Indianapolis, IN: Liberty Classics. Available at: https://eet.pixelonline.org/files/etranslation/original/The $\% 20$ Wealth\%20of\%20Nations.pdf (accessed 12 May 2019).

Smith A (2002) The Theory of Moral Sentiments. Cambridge: Cambridge University Press.

Somers MR (2018) Utopianism and the Reality of Society: Decoding Polanyi's Socialism, Freedom and The Alchemy of Misrecognition. In: Brie M and Thomasberger C (eds) Karl Polanyi's Vision of a Socialist Transformation. Montréal: Black Rose Books, pp. 91-109.

Somers MR and Block F (2014) The Return of Karl Polanyi. Dissent Magazine, Spring. Available at: http://www.dissentmagazine.org/article/the-return-of-karl-polanyi (accessed 25 November 2014).

Steyaert C and Dey P (2010) Nine Verbs to Keep the Social Entrepreneurship Research Agenda 'Dangerous'. Journal of Social Entrepreneurship 1(2): 231-254.

Stiglitz JE (2001) Foreword. In: The Great Transformation: The Political and Economic Origins of Our Time. Second Beacon Paperback Edition Published in 2001. Boston, MA: Beacon Press, pp. vii-xviii.

Stiglitz JE (2009) Moving Beyond Market Fundamentalism to a More Balanced Economy. Annals of Public and Cooperative Economics 80(3): 345-360.

Swedberg R (2003) Principles of Economic Sociology. Princeton, N.J.: Princeton University Press. 
Teasdale S (2012a) Guest Editorial. Social Enterprise Journal 8(2): 88-89. DOI: 10.1108/sej.2012.37308baa.001.

Teasdale S (2012b) Negotiating Tensions: How Do Social Enterprises in the Homelessness Field Balance Social and Commercial Considerations? Housing Studies 27(4): 514532.

Teasdale S (2012c) What's in a Name? Making Sense of Social Enterprise Discourses. Public Policy and Administration 27(2): 99-119. DOI: 10.1177/0952076711401466.

Tedmanson D, Verduyn K, Essers C, et al. (2012) Critical Perspectives in Entrepreneurship Research. Organization 19(5): 531-541. DOI: 10.1177/1350508412458495.

Tracey P, Phillips N and Jarvis O (2011) Bridging Institutional Entrepreneurship and the Creation of New Organizational Forms: A Multilevel Model. Organization Science 22(1): $60-80$.

Utting P (ed.) (2015) Social and Solidarity Economy: Beyond the Fringe? London: Zed Books.

Yunus M (2010) Building Social Business: The New Kind of Capitalism That Serves Humanity's Most Pressing Needs. New York: Public Affairs. 